\title{
CREATIVE THINKING SKILLS OF STUDENTS ON HARMONIC VIBRATION USING MODEL STUDENT FACILITATOR AND EXPLAINING (SFAE)
}

\author{
Adam Malik ${ }^{* 1}$, Yani Nuraeni ${ }^{2}$, Achmad Samsudin $^{3}$, Sutarno $^{4}$ \\ ${ }^{1,2}$ Department of Physics Education, UIN Sunan Gunung Djati Bandung, Indonesia \\ ${ }^{3}$ Department of Physics Education, Universitas Pendidikan Indonesia, Indonesia \\ ${ }^{4}$ Department of Physics Education, Universitas Bengkulu, Indonesia \\ *Correspondence address: adammalik@uinsgd.ac.id
}

Received: October 08 ${ }^{\text {th }}, 2018$. Accepted: April 10"th 2019 . Published: April 29 ${ }^{\text {th }}, 2019$

\begin{abstract}
This study aims to determine the implementation of learning by applying the Student Facilitator And Explaining (SFAE) model and the improvement of students' creative thinking skills on the topic of harmonic vibration. The method used in this study is pre-experimental with one-group pretest-posttest design. The samples of this study were students of class X MIA 4 SMA Karya Pembangunan I Ciaparay with a total of 30 students. The sample was chosen by random sampling technique. The field observation sheet instrument was used to observe the implementation of the SFAE model. An essay type test was given in order to measure students' creative thinking skills. This study discovers that the average implementation score of teacher's activity was $83 \%$ which belongs to the good category and the students' activity was $79 \%$ which belongs to the good category. The Improvement of students' creative thinking skills based on normalized gain was 0.56 which belongs to the medium category. Hypothesis testing used was paired sample t-test with the results of $t$-count (36.06)> t-table (2.052). This result means that the SFAE model can be used as an alternative for improving students' creative thinking skills for the topic of harmonic vibration. Thus, implementation of the SFAE model can improve students' higher order thinking skills. The SFAE model can also be implemented for learning on other physics topics at various levels of education.
\end{abstract}

(C) 2019 Physics Education, UIN Raden Intan Lampung, Indonesia

Keyword: creative thinking skills, harmonic vibration, SFAE model

\section{INTRODUCTION}

Education has a very important role to ensure the development and survival of a nation's life. Along with the rapid development of science and technology, education is a need that must be met. Education has a very important role to ensure the development and survival of a nation. Along with the rapid development of science and technology, education is a need that must be fulfilled. Educators in the 21 st century should prepare students to be creative in facing social problems in their daily lives (Hargrove, 2013). Based on the Regulation of the Ministry of Education and Culture number 21 of 2016 which states that to meet future needs and meet Indonesia's golden generation of 2045, a standard of graduate competence based on $21^{\text {st }}$-century competency has been established (Kementerian Pendidikan dan Kebudayaan, 2016). Students in the $21^{\text {st }}$ century must have various abilities such as learning and innovation skills (the ability to learn and innovate) their ideas: (1) critical thinking and problem solving, (2) communication and collaboration, (3) creativity and innovation (Trilling \& Fadel, 2009). Critical thinking and creative thinking are also major topics in contemporary education revolution worldwide (Chang, Li, Chen, \& Chiu, 2014).

The ability to learn and innovate is needed in the field of science, especially in the field of physics. Physics is one part of science is essentially a collection of knowledge, ways of thinking, and investigations that use scientific processes in finding a fact or concept (Etkina \& 
Heuvelen, 2007). The discipline of physics is built on the interplay of theory and experiment. Theory helps to give meaning to the results of experiments and guides new experimental directions. In turn, experimental measurements test predictions of theoretical models and help to refine these models to push the frontiers of physics knowledge (Wilcox \& Lewandowski, 2017). Physics learning in the 21 st-century requires students to have more creative ways of thinking (Gunawan, Harjono, Sahidu, \& Nisrina, 2018).

Creative thinking and creative abilities are increasingly being used in finding solutions to problems that impact on human progress and survival (Fields \& Bisschoff, 2014). The ability to think creatively is a way of thinking that can generate ideas, something new or different from those that have existed before in solving problems (Antink-meyer \& Lederman, 2015).

Learning in the 21 st-century requires a change in the role of students no longer an object but must be the subject of the learning process. The ability of the 21 stcentury in learning can be improved by making students as facilitators of learning not as objects of learning. Students who are involved in learning can practice communication skills in expressing ideas and opinions and practice thinking more critically and creatively (Hamza \& Hassan, 2016). This gap in curriculum and pedagogy calls for theoretical studies grounded in practice that enable educators to imagine the possibilities of various forms of creativity present in their practices and to articulate their potential significances for learning (Hwang, 2016). The success of physics learning is very dependent on education implementers, namely teachers (Basson \& Kriek, 2012). Teachers must implement effective and efficient learning in line with the 2013 curriculum implementation (Sani, 2013). The teacher must be a facilitator for students in developing their competence so that they have the life skills needed in the 21st-century (Suherman, 2008).

Teachers have not been able to carry out learning activities in accordance with process standards, namely teachers not accustomed to conveying the competencies to be achieved by students, have not implemented contextual and scientific learning, have not facilitated students to process or analyze information to make a conclusion (Kustijono \& Wiwin, 2014). The teacher's habit of applying conventional models when explaining the concept of physics makes students less fond of learning because they consider physics learning less attractive and difficult to understand.

Based on the objectives of physics learning that has been stated earlier, the teacher must change the learning paradigm from a teacher-centered approach to a student-centered approach. Effective student-centered learning not only involves students but also ownership by the teacher through practice that is relevant to student and teacher alike (McGlashan, 2018). Physics learning that involves students can actively train creative thinking skills, therefore, so that students do not think that physics is difficult to understand, a teacher must have the competence to develop learning models to be more varied. One learning model that can be applied is a cooperative learning model type Student Facilitator And Explaining (SFAE) (Nopearti, Yelniati, Azmi, \& Abdullah, 2016). The cooperative learning model is a learning model where students work in small groups to help each other in learning the subject matter (Slavin, 2009). The SFAE learning model makes students as facilitators and invited to think creatively so as to produce a more in-depth and interesting exchange of information and create confidence in students to produce work that is shown to their friends. 
Several previous studies related to the SFAE type of cooperative learning model were conducted, it showed the SFAE model could improve the critical thinking skills of students in the topic of momentum and impulse (Malik, Vitriani, \& Chusni, 2018). Besides, there was an effect of the SFAE type of cooperative learning model with a scientific approach to physics learning outcomes (Bayuaji, Hikmawati, \& Rahayu, 2017). Furthermore, it was found that the SFAE learning model with the media of the dream wheels containing question cards had a positive effect on student learning outcomes of chemical concepts (Fatimah, Sumarti, \& Wardani, 2017). Other researchers stated that there was an effect of problem-based learning to learn model combined with the SFAE model on the ability to think critically in the fungus sub-concept (Setiawan, Budiretnani, \& Utami, 2017). There were differences in mathematical critical thinking skills among students taught using SFAE and expository learning models (Hasan, Trapsilasiwi, \& Setiawani, 2017). The application of the SFAE type cooperative learning model can improve a student's mathematics learning achievement on the straight-line equation concept (Arum, Budiyono, \& Kurniawati, 2017). Besides, mathematical problem-solving abilities of students who take cooperative learning with the SFAE method were better rather than direct learning (Muslim, 2014). Based on the description of student learning outcomes by applying the SFAE model was better than the conventional model. The SFAE type of cooperative learning model gives of students the opportunity to express their ideas and opinions in responding to problems and requires students to think creatively, actively and meticulously to the problems so as to improve learning outcomes.

Previous research of SFAE model was applied to measure critical thinking, students' learning outcomes, learning achievement and problem-solving skills in math and science concept. The difference from this study was the dependent variable measured the creative thinking skills of students on harmonic vibration concept.

\section{METHOD}

The research method used in this study was the pre-experimental with type onegroup pretest-posttest design. This study was conducted on one group of students without any control group. The researcher in this design made an initial measurement (pretest) of students' creative thinking skills, then gave treatment for the form of the application of the SFAE model.

The populations that will be studied are all X MIA classes of SMA Karya Pembangunan 1 Ciparay with a total of four classes. The sample of the study was class X MIA 4 with a total of 30 students. The sampling technique uses simple random sampling technique. Simple random sampling is a sampling technique where every item in the population has an even chance and likelihood of being selected in the sample.

The stages of the SFAE model are as follows: (1) teacher conveys the competencies to be achieved, (2) teacher demonstrates the concept, (3) teacher gives students the opportunity to explain to other students for example through concept charts/maps, (4) teacher brings together students' ideas and opinions, (5) teacher explains all the concepts presented at the session, (6) Closing arguments presented (Suprijono, 2009).

The success rate of the implementation of the SFAE model was measured using a field observation sheet filled by observers. The data obtained were then analyzed quantitatively and qualitatively based on observations. The concept discussed in this study was simple harmonic vibration with subtopic in simple harmonic motion in a different rope pendulum, simple 
harmonic movements in different load mass pendulum and simple harmonic movements on springs. Harmonic vibration concept was a concept suitable to be used to train students' creative thinking skills because it's contextual and closely related to everyday life. Aspects of creative thinking skills that were trained in this study according to Guilford and Torrance, namely fluency, flexible thinking, originality, and elaboration (Almeida, Prieto, Ferrando, Oliviera, \& Ferrandiz, 2008). Creative thinking skills were trained by using student activity sheets during learning with the SFAE model. The data obtained were-then analyzed and interpreted to find out the achievement of student grades. After being given treatment for the SFAE model, the researcher made a measurement again of the students' creative thinking skills (posttest).

The creative thinking skills test used was six items. The test was used to determine the achievement and the significance of aspects of creative thinking skills of students. Before conducting a quantitative analysis of the test of creative thinking skills, each item was tested first and then analyzed quantitatively which included tests of validity, reliability, differentiation, and level of difficulty through calculation.

Analysis of observation sheet data was done by calculating the percentage of learning implementation by applying the SFAE model. The results of the analysis are then interpreted using the criteria for learning implementation according to Purwanto (2008) can be seen in Table 1 .

Table 1. Implementation Criteria of the SFAE Model

\begin{tabular}{cc}
\hline Mastery Level & Criteria \\
\hline $86 \%-100 \%$ & Very good \\
$76 \%-85 \%$ & Good \\
$60 \%-75 \%$ & Enough \\
$55 \%-59 \%$ & Less \\
$\leq 54 \%$ & Very lacking \\
\hline
\end{tabular}

The qualitative analysis was carried out based on observer comments when implementing the SFAE model. Data analysis of student activity sheets was carried out by calculating the percentage of student answers and interpreted to determine the achievement of student scores and improvement of creative thinking skills that were trained after conducting learning activities with the SFAE model. Criteria for achieving student score according to Arikunto (2012) can be seen in Table 2.

Table 2. Criteria of Students' Achievement

\begin{tabular}{cc}
\hline Value & Interpretation \\
\hline$<40$ & Failed \\
$40-55$ & Less \\
$56-65$ & Enough \\
$66-79$ & Good \\
$80-100$ & Very good \\
\hline
\end{tabular}

As for knowing the increase in students' creative thinking ability, a normalized gain $\langle\mathrm{g}\rangle$ analysis was performed on the results of the students' pretest and posttest. Hypothesis testing is used to determine the significance of improving students' creative thinking skills. The normalized gain values obtained are then interpreted according to the criteria according to Hake (1998) can be seen in Table 3.

Table 3. Criteria for N-gain Values

\begin{tabular}{cc}
\hline $\mathbf{N}$-gain values & Criteria \\
\hline$\langle\mathrm{g}\rangle\langle 0,3$ & Low \\
$0,3 \leq\langle\mathrm{g}\rangle \leq 0,7$ & Medium \\
$\langle\mathrm{g}\rangle>0,7$ & High \\
\hline
\end{tabular}

The normality test checks the assumption for the statistic. The normality test was carried out using the Lilliefors test. Then the hypothesis testing using a paired sample t-test for normally distributed data and Wilcoxon test for data that were not normally distributed were conducted. 
RESULTS AND DISCUSSION

Results

Implementation of Student Facilitator and Explaining (SFAE) Model

The implementation of the SFAE model is the treatment given to improve students' creative thinking skills students in harmonic vibration concept. The treatment was given three meetings. The results of the observation sheet of the implementation of each stage of the SFAE model can be seen in Table 4 .

Table 4. Analysis of the Implementation Observation Sheet of SFAE Model

\begin{tabular}{|c|c|c|c|c|}
\hline \multirow{2}{*}{$\begin{array}{c}\text { Learning stages SFAE } \\
\text { model }\end{array}$} & \multicolumn{4}{|c|}{ Implementation of activities } \\
\hline & Teacher $(\%)$ & Interpretation & Student (\%) & Interpretation \\
\hline Preliminary & 81 & Good & 77 & Good \\
\hline Delivering the competencies & 83 & Good & 78 & Good \\
\hline Demonstrating the concept & 79 & Good & 76 & Good \\
\hline Presenting of concept & 78 & Good & 74 & Enough \\
\hline Concluding students' ideas & 86 & Very Good & 82 & Good \\
\hline $\begin{array}{l}\text { Explaining all concept } \\
\text { presented }\end{array}$ & 87 & Very Good & 83 & Good \\
\hline Closing & 85 & Good & 83 & Good \\
\hline Average & 83 & Good & 79 & Good \\
\hline
\end{tabular}

The teacher and student activity of each stage of the SFAE type cooperative learning model at each meeting have increased. Averagely improvement activity of teachers and students at each stage including good categories. The highest implementation both in teacher and student activities occurs in explaining all concept stages. The lowest implementation of teacher activities and students occurs in the presenting of concept.

\section{Students' Creative Thinking Skills}

Based on the results of the analysis of the student's pretest and posttest scores, an increase in student's creative thinking skills can be seen through the average normalized gain $\langle\mathrm{g}\rangle$ of students in Table 5.
Table 5. The Improvement of Students' Creative Thinking Skills

\begin{tabular}{cccc}
\hline & Pretest & Posttest & N-gain \\
\hline Amount & 904 & 2075 & 0.56 \\
Average & 30 & 69 & \\
\hline
\end{tabular}

The students' creative thinking skills before the application of the SFAE model (pretest) showed an average value of 30 . After the implementation of the SFAE model, the results of the posttest showed an average of 69 . The average creative thinking skills of students experienced an increase of 39. There was an increase in students' creative thinking skills after being applied to the SFAE model with normalized gain $\langle\mathrm{g}\rangle 0.56$ include the medium category.

The distribution of pretest-posttest scores after the calculation and analysis of $<\mathrm{g}>$ students on each subconcept harmonic vibration can be seen in Table 6.

Table 6. The Improvement for Each Sub-concept of Harmonic Vibration

\begin{tabular}{|c|c|c|c|c|c|}
\hline \multirow[t]{2}{*}{ No } & \multirow[t]{2}{*}{ Sub-concept } & \multicolumn{3}{|c|}{ Value } & \multirow[t]{2}{*}{ Interpretation } \\
\hline & & Pretest & Posttest & $\langle\mathrm{g}\rangle$ & \\
\hline 1 & $\begin{array}{l}\text { Simple harmonic motion in a different length rope } \\
\text { pendulum }\end{array}$ & 27.08 & 75.83 & 0.67 & Medium \\
\hline 2 & $\begin{array}{l}\text { Simple harmonic movements in different load mass } \\
\text { pendulum }\end{array}$ & 25.42 & 69.58 & 0.59 & Medium \\
\hline \multirow[t]{2}{*}{3} & Simple harmonic movements on springs & 37.92 & 62.08 & 0.39 & Medium \\
\hline & Average & 30.14 & 69.17 & 0.55 & Medium \\
\hline
\end{tabular}


The improvement of students' creative thinking skills in each subconcept of harmonic vibration is included in the medium category. The highest improvement occurred in the subconcept of simple harmonic motion in a different rope pendulum including the medium category. The lowest improvement occurred in the subconcepts of simple harmonic movements on springs including the medium category.

The normalized distribution gain $\langle\mathrm{g}\rangle$ of students in each aspect of creative thinking skills (CTS) can be seen in Table 7.

Table 7. The increased aspect of creative thinking skills

\begin{tabular}{|c|c|c|c|c|c|}
\hline \multirow[t]{2}{*}{ No. } & \multirow{2}{*}{$\begin{array}{c}\text { Indicator of } \\
\text { CTS }\end{array}$} & \multicolumn{3}{|c|}{ Value } & \multirow{2}{*}{$\begin{array}{c}\text { Interpre } \\
\text { tation }\end{array}$} \\
\hline & & $\begin{array}{c}\text { Pre- } \\
\text { test }\end{array}$ & Post-test & $\langle\mathrm{g}\rangle$ & \\
\hline 1 & Fluency & 21.25 & 65.00 & 0.56 & $\mathrm{M}$ \\
\hline 2 & Flex & 35.83 & 70.00 & 0.53 & um \\
\hline \multirow[t]{2}{*}{3} & $\begin{array}{l}\text { Originality, } \\
\text { Elaboration }\end{array}$ & 33.33 & 62.50 & 0.44 & Medium \\
\hline & Average & 30.14 & 65.83 & 0.51 & Medium \\
\hline
\end{tabular}

The increased every aspect of students' creative thinking skills is included in the medium category. The highest increase occurred in the fluency aspect including the medium category. The aspect of originality, elaboration experienced the lowest increase compared to other aspects including the medium category.

Distribution of normalized gain $\langle\mathrm{g}\rangle$ students in every aspect of creative thinking skills (CTS) in each category can be seen in Table 8 .

Table 8. The improvement of students' creative thinking skills in each category

\begin{tabular}{llccl}
\hline No & $\begin{array}{c}\text { Indicator } \\
\text { of CTS }\end{array}$ & $\begin{array}{c}\text { The } \\
\text { Number }\end{array}$ & $\begin{array}{c}\text { Percentage } \\
(\%)\end{array}$ & Category \\
\hline 1 & Fluency & 0 & 0 & Low \\
& & 27 & 90 & Medium \\
& & 3 & 10 & High \\
2 & Flexibility & 0 & 0 & Low \\
& & 18 & 60 & Medium \\
& & 12 & 40 & High \\
3 & Originality, & 9 & 30 & Low \\
& Elaboration & 20 & 66 & Medium \\
& & 1 & 3 & High \\
\hline
\end{tabular}

The number of students who experienced an increase in the low category in the originality elaboration aspect was the most compared to other aspects. The number of students in the aspect of flexibility experienced an increase in the high category which showed the most compared to other aspects.

\section{Hypothesis Testing}

Hypothesis testing was used to determine the significance of improving students' creative thinking skills. The procedure adopted in testing the hypothesis was the normality test and hypothesis testing. The results of the normality test of data pretest and posttest using the liliefors test obtained pretest data was L-counted $(0.120)<$ L-table (0.161) with a significance level of 0.05 , indicating that the pretest data were normally distributed. Posttest data were known L-count $(0.088)<$ L-table $(0.161)$ with a significance level of 0.05 , indicating the posttest data was normally distributed. Hypothesis testing using paired sample t-test obtained $t$-counted (36.06) > t-table (2.052) at the significance level of 0.05 . The results of the calculation and analysis show that $\mathrm{H}_{0}$ was rejected and $\mathrm{H}_{1}$ was accepted, so that there was an effect of the application of SFAE model to improve students' creative thinking skills in harmonic vibration concept in class X MIA 4 SMA Karya Pembangunan 1 Ciparay.

The results of the relationship analysis of the value of students' creative thinking skills with student activity sheets can be seen in Table 9.

Table 9. The relationship of scores of students' creative thinking skills with student activity sheets

\begin{tabular}{|c|c|c|c|c|c|c|}
\hline \multirow[t]{2}{*}{$\overline{\text { No }}$} & \multirow{2}{*}{$\begin{array}{c}\text { Indicator of } \\
\text { CTS }\end{array}$} & \multicolumn{3}{|c|}{ Lesson to } & \multirow{2}{*}{$\begin{array}{c}\text { Aver } \\
\text { age }\end{array}$} & \multirow{2}{*}{$\begin{array}{c}\text { Interpret } \\
\text { ation }\end{array}$} \\
\hline & & 1 & 2 & 3 & & \\
\hline \multirow[t]{2}{*}{1} & Fluency & 6 & 8 & 9 & 80 & Very \\
\hline & & 5 & 5 & 0 & & good \\
\hline \multirow[t]{2}{*}{2} & Flexibility & 6 & 6 & 8 & 68 & Good \\
\hline & & 0 & 5 & 0 & & \\
\hline \multirow[t]{4}{*}{3} & Originality, & 4 & 6 & 7 & 57 & Enough \\
\hline & Elaboration & 0 & 0 & 0 & & \\
\hline & Average & 5 & 7 & 8 & 68 & Good \\
\hline & & 5 & 0 & 0 & & \\
\hline
\end{tabular}


Based on the results of the student activity sheet the biggest increase in indicators of creative thinking skills from the first to the third meeting is fluency. The average increase was 80 including very good categories. The originality and elaboration indicators experienced the lowest increase compared to other indicators for three meetings. The average increase was 57 including enough categories.

\section{Discussion}

The results of the implementation analysis of each meeting using the SFAE model, it can be seen that the highest percentage of activities carried out by the teacher and students was the stage of explaining all the concept presented. The teacher at this stage explains or gives reinforcement of the concept that has been explained by students. Students who previously held discussions and presentations, when the teacher explained the concept students noticed the explanations made by the teacher. The SFAE model provides a learning experience of students to process the concept learned by the process of thinking, exchanging information, evaluating and re-expressing the concepts learned and communicating to other students (Yunita, Slamet, \& Santoso, 2017).

The lowest percentage of activities carried out by the teacher and students was the stage of presenting the concept. This stage consists of several activities of teachers and student, one of which is the teacher displaying videos and students conducting experiments. The low stages are caused by several factors such as technical errors when displaying videos or conducting experiments. Students are not used to doing experiments because previously they have never conducted physics experiments, and students have not understood the work procedures contained in the worksheet provided by the teacher. Experimental activities can improve students' creative thinking skills and mastery of students' physics concepts and provide opportunities for students to practice scientific methods (Hermansyah, Gunawan, \& Herayanti, 2015).

The implementation of the SFAE model there are several advantages, can improve students' creative thinking skills, introduce students to learning variations, make students as a teacher explain the concept in front of the class, train students' abilities in expressing opinions, respect people's opinions others and train students' self-confidence by way of discussion and presentation. The SFAE model gives students the opportunity to share their opinions or ideas in understanding a problem so that their knowledge capacity increases in the thought contribution to other students and guidance of the teacher (Bayuaji, Hikmawati, \& Rahayu, 2017). The advantages of the SFAE model one of which is to train students to become teachers because students are given the opportunity to repeat the teacher's explanations that have been heard and know the student's abilities in conveying ideas (Huda, 2014).

The application of the SFAE model in this study also has weaknesses in its implementation. For example, inadequate school facilities such as the absence of a projector in the classroom so that the appearance of the problems contained in the video related to learning are less effective. Students rarely conduct physics experiments so that when conducting experiments, it is less effective because students are still confused with the experiment work procedures. Besides, students are rarely trained to discuss so that discussions are less active and students lack confidence in making presentations in front of the class. The weaknesses for the SFAE model, one of which is that shy students are often difficult to present what is instructed by 
the teacher, not all students have the same opportunity to explain back to their friends due to limited learning time (Huda, 2014). Teaching for creative thinking should include three principles: diversity and vivid teaching strategies, emphasis on cultivating students' creativity and developing student-focused teaching (Ku \& Kuo, 2014).

Based on the results of the pretest and posttest analysis there was an increase in students' creative thinking skills. This can be seen from the average value of the students' pretest and posttest. Overall, the average gain normalized by students' creative thinking skills is in the medium category. This means that there is influence before and after the application of the SFAE model in improving students' creative thinking skills

Based on the data analysis of the increase of each sub concept, it was obtained the highest average of normalized gain, namely the concept of simple harmonic vibration in the pendulum with a different rope length including the medium category. Most students are more interested in the pendulum concept, because the pendulum phenomenon is related to daily life, namely about swing, so students can answer questions quite easily. This was marked by an increase before learning and after learning using the SFAE type cooperative learning model. The questions developed to measure students' high-level thinking skills contained real physics phenomena and needed high-level thinking skills in their completion (Kirana \& Wasis, 2014).

The lowest average of the normalized gain of each subconcept is simple harmonic vibration concept on the spring including the medium category. This is because students have not received prior information about the application of springs in everyday life, so students feel difficulties when working on the questions. The high-level thinking ability required someone to apply new information or prior knowledge and manipulate information to reach possible answers (Rofiah, Aminah, \& Ekawati, 2013). The field of Physics has a sufficient range to promote creativity in its own domain, and therefore creativity can be brought up in the context of learning physics (Alrubaie, \& Daniel, 2014).

The flexibility aspect reaches the highest increase compared to other aspects of creative thinking skills. The average normalized gain of flexibility aspect is included in the medium category. Students begin to be able to express their ideas about the causes that occur to a phenomenon verbally. The increase in verbal creativity was higher due to the different levels of questions. Verbal creativity tests are easier for students to solve because they only propose ideas based on physical phenomena in the discourse presented (Fitriani, Gunawan, \& Sutrio, 2017).

The lowest average of normalized gain on each aspect of creative thinking skills is the originality and elaboration aspects including the medium category. Students have not been able to make and describe new product designs in detail to improve existing products. The product presented in the question is related to the application of the concept of harmonic vibration. Examples of questions related to aspects of originality and elaboration students are asked to design a new pogo stick that can jump high, then explain the reason for making the new design. The results of this study are in accordance with previous research, the originality aspect of creative thinking skills tends to be more difficult to improve compared to other aspects (Setiawan, Malik, Suhandi, \& Permanasari, 2018; Malik, Setiawan, Suhandi, \& Permanasari, 2017; Malik, Ruswandi, Setiawan, Suhandi, \& Permanasari, 2017). The figural creativity test requires high concentration to answer 
questions because students are asked to make or complete the picture into a single meaningful picture (Fitriani, Gunawan, \& Sutrio, 2017).

Data obtained from the results of hypothesis testing using t-test obtained data t-count $>$ table. This shows that the implementation of SFAE type cooperative learning model can improve students' creative thinking skills. This is because during the learning process students are conditioned to study in groups and issue their ideas and opinions in the form of asking questions or making new products in solving a problem, and students are taught to actively participate during the learning process.

The improvement on students creative thinking skills is in line with the research conducted by (Fatimah, Sumarti, \& Wardani, 2017) which states that the SFAE learning model with the question wheel media contains question cards has a positive effect on student learning outcomes of chemical concepts. According to (Zahra, Widyawati, \& Ningsih, 2017) students that applied SFE type cooperative learning model assisted with imagination box props have better mathematics learning achievement than students who applied direct learning models. Another study conducted by (Sari, 2014) stated that students' creative thinking ability of mathematics using the SFAE-type cooperative learning model is better than students who learn to use the expository model.

Based on several studies above and the results of research conducted by the author, it can be concluded that the SFAE model can be used as an alternative learning model that can be used to improve students' creative thinking skills in any concept.

\section{CONCLUSION AND SUGGESTION}

We have successfully conducted research on the application of the SFAE model to improve students' creative thinking skills related to the concept of harmonic vibration. The implementation of SFAE model obtained by the average teacher activity was $83 \%$ in the good category and the average student activity was $79 \%$ in the good category. The improvement of students' creative thinking skills related to the concept of harmonic vibration after applying the SFAE model including the medium category with an average normalized gain of 0.56. Thus, the SFAE model can be applied to improve other high-level thinking skills and other physics concepts.

Recommendations are submitted as a reference for further research, the teacher should guide and direct each experiment activity and discussion conducted by students in a more comprehensive manner. Teachers are advised to more often train every aspect of students' creative thinking skills, especially related to students' ability to think originally and elaboration thinking by creating something new and adding useful values to something.

\section{REFERENCES}

Almeida, L. S., Prieto, L. P., Ferrando, M., Oliviera, E., \& Ferrandiz, C. (2008). Torrance test of creative thinking: The question of its construct validity. Thinking Skills and Creativity, 3, 53-58.

Alrubaie, F., \& Daniel, E. G. S. (2014). Developing a creative thinking test for iraqi physics students. International Journal of Mathematics and Physical Sciences Research, 2(1), 80-84.

Antink-meyer, A., \& Lederman, N. G. (2015). Creative cognition in secondary science: An exploration of divergent thinking in science among adolescents. International Journal of Science Education, 37(10), 15471563.

Arikunto, S. (2012). Dasar-dasar Evaluasi Pendidikan. Jakarta: Bumi 
Aksara.

Arum, A. T., Budiyono, \& Kurniawati, I. (2017). Upaya meningkatkan aktivitas belajar dan prestasi belajar matematika siswa melalui penerapan model pembelajaran kooperatif tipe student facilitator and explaining (sfe) pada materi persamaan garis lurus bagi siswa kelas VIII SMP negeri 2 Sukoharjo. Jurnal Pendidikan Matematika dan Matematika, 1(1), 15-18.

Basson, I., \& Kriek, J. (2012). Are grades 10-12 physical sciences teachers equipped to teach physics? university of south africa. Perspectives in Education, 30(3), 110-121.

Bayuaji, P., Hikmawati, \& Rahayu, S. (2017). Pengaruh model pembelajaran kooperatif student facilitator and explaining (sfae) dengan pendekatan saintifik terhadap hasil belajar fisika. Jurnal Pijar MIPA, 12(1), 15-18.

Chang, Y., Li, B., Chen, H., \& Chiu, F. (2014). Investigating the synergy of critical thinking and creative thinking in the course of integrated activity in Taiwan. Educational Psychology, 1-20.

Etkina, E., \& Heuvelen. A. H. (2007). Investigative science learning environment-a science process approach to learning physics abstract: Table of contents. Research-Based Reform of University Physics, 1-48.

Fatimah, N., Sumarti, S. S. \& Wardani. (2017). Pengaruh student facilitator and explaining dengan roda impian terhadap hasil belajar siswa. Jurnal Chemistry in Education, 6(2), 1-8.

Fields, Z., \& Bisschoff, C. A. (2014). Developing and assessing a tool to measure the creativity of university students. J Soc Sci, 38(1), 23-31.

Fitriani, N., Gunawan, \& Sutrio. (2017). Berpikir kreatif dalam fisika dengan pembelajaran

conceptual understanding procedures (CUPs) berbantuan LKPD. Jurnal Pendidikan Fisika dan Teknologi, 3(1), 24-33.

Gunawan, Harjono, A., Sahidu, H., \& Nisrina. (2018). Improving students' creativity using cooperative learning with virtual media on static fluida concept. Journal of Physics: Conf. Series, 1006(1), 012016-1-6.

Hake, R. R. (1998). Interactiveengagement versus traditional methods: A six thousand-student survey of mechanics test data for introductory physics courses. American Journal of Physics, 66, 64-74.

Hamza, T. S., \& Hassan, D. K. (2016). Consequential creativity student competency and lateral thinking incorporation in architectural education. International Journal of Technology and Design Education 26(4), 587-612. http://dx.doi.org/10.1007/s10798015-9321-4.

Hargrove, R. A. (2013). Assessing the long-term impact of a metacognitive approach to creative skill development. Int $J$ Technol Des Educ, 23, 489-517.

Hasan, A. Z., Trapsilasiwi, D., \& Setiawani, S. (2017). Perbandingan kemampuan berpikir kritis matematika antara siswa yang diajar menggunakan model pembelajaran student facilitator and explaining (sfae) dan ekspositori di kelas VIII MTs negeri Jember 1. Jurnal Edukasi, 4(2), 52-57.

Hermansyah, Gunawan, \& Herayanti, L. (2015). Pengaruh penggunaan laboratorium virtual terhadap penguasaan konsep dan kemampuan berpikir kreatif siswa pada materi getaran dan gelombang. Jurnal Pendidikan Fisika dan Teknologi, 1(2), 97-102.

Huda, M. (2014). Model-model 
Pengajaran dan Pembelajaran. Yogyakarta: Pustaka Pelajar.

Hwang, S. Y. (2016). Rethinking creativity: Present in expression in creative learning communities. Educational Philosophy and Theory 1857 , $1-11$. http://dx.doi.org/10.1080/00131857. 2016.1225559.

Kementerian Pendidikan dan Kebudayaan. 2016. Peraturan Menteri Pendidikan dan Kebudayaan Nomor 21 Tahun 2016. Jakarta: Kementrian Pendidikan dan Kebudayaan.

Kirana, I. E., \& Wasis. (2014). Pengembangan soal-soal pengetahuan untuk mengukur kemampuan berpikir tingkat tinggi siswa pada materi fluida SMA. Jurnal Inovasi Pendidikan Fisika, 4(1), 1-14.

Ku, Y., \& Kuo, C. (2014). Develop a framework of creative thinking teaching mode for RN-BSN students on the basis of the creative process of clinical nurses in Taiwan. Innovations in Education and Teaching International, 53(4), 42434.

Kustijono, R., \& Wiwin, E. (2014). Pandangan guru terhadap pelaksanaan kurikulum 2013 dalam pembelajaran fisika SMK di kota Surabaya. Jurnal Pendidikan Fisika Dan Aplikasinya (JPFA), 4(1), 1-14.

Malik, A., Setiawan, A., Suhandi, A., \& Permanasari, A. (2017). Enhancing pre-service physics teachers' creative thinking skills through hot lab design. In AIP Conference Proceedings, 1868(1), 070001-1-7.

Malik, A., Ruswandi, U., Setiawan, A., Suhandi, A., \& Permanasari, A. (2017). How to improve creative thinking skills of pre-service physics teachers?. In 2nd International Conference on Sociology Education (ICSE 2017), 1063-67.
Malik, A., Vitriani, \& Chusni, M. M. (2018). Improving students' criticalthinking skills through student facilitator and explaining model in momentum and impulse topic. JPPPF (Jurnal Penelitian dan Pengembangan Pendidikan Fisika) 4(2), 55-64.

McGlashan, A. (2018). A pedagogic approach to enhance creative "ideation" in classroom practice. International Journal of Technology and Design Education, 28(2), 377393.

Muslim, S. R. (2014). Pengaruh penggunaan metode student facilitator and explaining dalam pembelajaran kooperatif terhadap kemampuan pemecahan masalah matematik dan kemampuan berpikir kritis matematik siswa SMK di kota Tasikmalaya. Jurnal Pendidikan Dan Keguruan, 1(1): 1-9.

Nopearti, M., Yelniati, Azmi, J., \& Abdullah. (2016). The implementation of cooperative type student facilitator and explaining (sfae) learning model use the concept map media to increase students achievement in reduction and oxidation reaction topic at $\mathrm{X}$ MIA SMAN 2 Pekanbaru." In The 1st Annual International Seminar on Transformative Education And Educational Leadership (AISTEEL), 315-18.

Purwanto, N. (2008). Prinsip-prinsip dan Teknik Evaluasi Pengajaran. Bandung: PT. Remaja Rosdakarya.

Rofiah, E., Aminah, N. S., \& Ekawati, E. Y. (2013). Penyusunan instrumen tes kemampuan berpikir tingkat tinggi fisika pada siswa SMP. Jurnal Pendidikan Fisika, 1(2), 17-22.

Sani, R. A. (2013). Inovasi Pembelajaran. Jakarta: Bumi Aksara.

Sari, T. I. (2014). Penerapan model pembelajaran kooperatif tipe student facilitator and explaining berbantuan 
kartu soal terhadap kemampuan pemecahan masalah matematika siswa kelas VIII SMP negeri 2 Ulujami. Jurnal Pendidikan Matematika, 2(2), 7-17.

Setiawan, A., Malik, A., Suhandi, A., \& Permanasari, A. (2018). Effect of higher order thinking laboratory on the improvement of critical and creative thinking skills. IOP Conference Series: Materials Science and Engineering, 306(1), 17.

Setiawan, M. A, Budiretnani D. A., \& Utami, B. (2017). Pengaruh model pembelajaran problem based learning dipadu student facilitator and explaining terhadap kemampuan berpikir kritis siswa kelas X SMAN 6 Kediri pada pokok bahasan fungi. Jurnal Florea, 4(1), 1-4.

Slavin, R. E. (2009). Cooperative Learning. Bandung: Nusa Media.

Suherman, E. (2008). Model belajar dan pembelajaran berorientasi kompetensi siswa. Jurnal Pendidikan dan Budaya, 5(2), 1-31.

Suprijono. (2009). Cooperative Learning (Teori \& Aplikasi PAIKEM). Yogyakarta: Pustaka Pelajar.

Trilling, B., \& Fadel, C. (2009). 21st Century Skills: Learning for Life in Our Times. San Francisco: John Wiley \& Sons, Inc.

Wilcox, B. R., \& Lewandowski, H. J. (2017). Students' views about the nature of experimental physics. Rev. Phys. Educ. Res., 13, 020110-1-10.

Yunita, D, Slamet, A \& Santoso, L. M. (2017). Pengaruh penerapan model pembelajaran kooperatif tipe student facilitator and explaining (SFE) terhadap penguasaan konsep peserta didik kelas XI SMA negeri 1 Talang Kelapa materi sistem ekskresi. In Prosiding Seminar Nasional Pendidikan IPA, 480-92.

Zahra, C., Widyawati, S., \& Ningsih, E. F. (2017). Eksperimentasi model pembelajaran kooperatif tipe student facilitator and explaining (sfe) berbantuan alat peraga kotak imajinasi ditinjau dari kecerdasan spasial. Jurnal Ilmiah Pendidikan Matematika, 2(2), 97-104. 